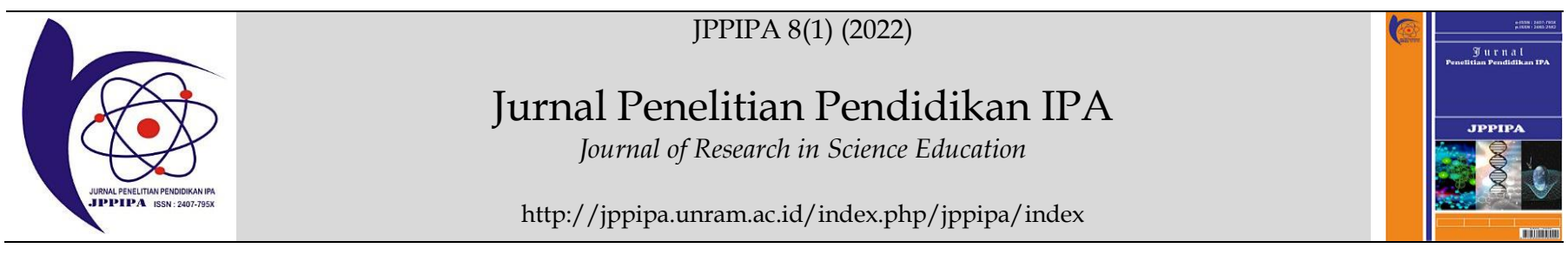

\title{
Application of Integrated Project-based and STEM-based E-learning Tools to Improve Students' Creative Thinking and Self-Regulation Skills
}

\author{
Molani Paulina Hasibuan ${ }^{1 *}$, Ratih Permana Sari ${ }^{1}$, Ricky Andi Syahputra ${ }^{2}$, Nahadi ${ }^{3}$ \\ ${ }^{1}$ Department of Chemistry Education, Universitas Samudra, Langsa, Indonesia. \\ 2 Department of Chemistry, Universitas Negeri Medan, Medan, Indonesia \\ ${ }^{3}$ Department of Chemistry Education, Universitas Pendidikan Indonesia, Bandung, Indonesia
}

DOI: $10.29303 /$ jppipa.v8i1.1050

\section{Article Info}

Received: October 19, 2021

Revised: December 24, 2021

Accepted: January 5, 2022

Published: Januari 31, 2022

\begin{abstract}
In today's digital environment, using technology in learning is a requirement for staying relevant to the needs of the twenty-first century. The goal of this study is to develop learning tools that combine Project-based learning (PjBL) with STEM-based elearning to assist students enhance their creative thinking skills and self-regulation. This study is a quantitative descriptive study using a one-shot case study research design and a research sample of 25 high school students in class for the academic year 2020/2021. The NGain score is used to collect data using test and non-test instruments before and after treatment to assess if there is an improvement in learning outcomes. All indicators of critical thinking skills and self-regulation increased as a result of the study. On the fluency indicator, the creative thinking skills indicator received the highest score of 0.86 , while selfregulation received the biggest rise on the organizing and transforming indicator with a score of 0.83 . The average increase in critical thinking skills is 73.66 percent, and the average rise in self-regulation is 79.42 percent, both of which are high.
\end{abstract}

Keywords: PjBL; STEM; e-learning; creative thinking skills; self-regulation

Citation: Hasibuan, M.P., Sari, R.P., Syahputra, R.A., \& Nahadi, N. (2022). Application of Integrated Project-based and STEM-based E-learning Tools to Improve Students' Creative Thinking and Self-Regulation Skills. Jurnal Penelitian Pendidikan IPA, 8(1), 51-56. https://doi.org/10.29303/jppipa.v8i1.1050

\section{Introduction}

Learning technology is a modern application or media that is utilized as a source of learning in both theory and practice. The characteristics of a fully internet-connected society are relevant to the employment of technology in the implementation of learning in the digital era. The internet has been utilized for a variety of purposes, including communication, information, entertainment, and most notably in the field of education (Dhahir, 2018). The use of internetbased learning technology advancements, often known as e-learning, can help students achieve better learning outcomes.
The focus of 21st-century skills development is no longer merely on low-level thinking skills, such as grasping concepts and applying them, but also on higher-order thinking skills (Hasanah, et al., 2021). The Assessment and Teaching of 21st Century Skills (ATC21S) divide 21st-century skills into four domains: thinking, working, working tools, and living in the world skills (Winaya, et al., 2016). In fact, higher-order thinking skills education in Indonesia is still lacking, one of which is creative thinking skills (Syukri, et al., 2021).

Some abstract concepts in science, particularly chemistry, make it difficult for students and teachers to comprehend the material being taught (Sanggara, et al., 2018; Nashihuddin \& Aulianto, 2017). Students are not

\footnotetext{
*Email: molanipaulinahsb@unsam.ac.id
} 
as interested in the process of developing a thought in their minds, which leads to a lack of creative thinking skills ( Husein, et al., 2015). According to the findings of unstructured interviews with chemistry teachers at Langsa senior high school, it was difficult to build elearning-and there was a lack of variety of learning models utilized in learning activities in the implementation of learning.

The Project Based Learning (PjBL) model, according to Rahardjanto, et al., (2019), is an effective learning model for focusing learning on students so that they are more active and improve their creative thinking skills. According to Umar, (2016) PjBL is a learning approach in which students are directly involved in transferring knowledge through research activities in order to work on and complete a specific learning project. $\mathrm{PjBL}$ is an effective learning model for developing many basic skills that students must possess, such as thinking skills, decision-making skills, skills, and problem-solving skills, while also improving students' self-confidence and self-management (Kılınç, 2010).

STEM is an interdisciplinary approach in which academic concepts are combined with real-world lessons or problems so that students can apply science, technology, engineering, and mathematics in schools, communities, jobs, and global companies, allowing them to compete in the new economy. STEM strives to foster critical thinking, reasoning, teamwork, investigation, and creative skills in pupils that may be used to all aspects of their lives (Sasmita et al., 2021).

STEM-based PjBL learning is a learning methodology that groups students together to create a project that combines science, technology, engineering, and mathematics (Dywan \& Airlanda, 2020). STEMintegrated $\mathrm{PjBL}$ shares many of the same qualities as regular $\mathrm{PjBL}$, but it focuses more on the design process or until the prototype is ready.

The construction of the STEM-integrated PjBL model has a high level of feasibility in increasing students' science process skills, according to Syukri, et al., (2021) research. Students' higher order thinking skills are also improved through PjBL-STEM learning (Triana, et al., 2020).

Teenagers account for the majority of internet users in Indonesia. Teenagers who spend a lot of time on the internet are often unable to control their behavior, which leads to internet addiction. In fact, the more a person's proclivity for internet addiction, the worse the physiological and spiritual effects, such as the risk of insecurity or suffering from attention deficit hyperactivity disorder (ADHD) (Harahap, 2017; Dhahir, 2018).

For 21st century students, the utilization of STEM-PjBL learning tools based on e-learning is a relevant learning medium. For internet users, using internet-based learning technology can be a beneficial and enjoyable experience. The employment of elearning-based PjBL-STEM learning tools can enhance students' higher order thinking skills by forming good self-regulatory habits such as cognitive, emotional, behavioral, and situational regulation (Anindyta \& Suwarjo, 2014; Rachmah, 2015). As a result, academics are interested in studying the development of integrated project-based and STEM-based e-learning tools to improve students' self-regulation and creative skills.

This research focuses on the efforts made by chemistry teachers in senior high schools through the development of learning tools that raise students' selfregulation and creative abilities. The purpose of this study was to develop and see the feasibility and use of e-learning based PjBL integrated STEM learning tools to improve students' self-regulation and creative thinking abilities. With the results of this study, it is hoped that chemistry teachers in high schools can be more creative and innovative in the use of learning tools that raise students' self-regulation and creative abilities so that they are in line with the demands of 21st century competencies.

\section{Method}

This study is a descriptive quantitative study that uses tests and non-tests instrument to collect data. Descriptive research is study that explains things that are already applicable, whereas quantitative research is defined based on the type of data and the method numbers are processed and analyzed using statistical tests. This study took place at the Faculty of Teacher Training and Education, Chemistry Education Study Program in Samudra University and Senior High School 4 in Langsa City from July to September 2021. Purposive sampling was used to choose the research subjects, who were 26 students in class XI IPA for the academic year 2020/2021. The development of integrated project-based and STEM-based e-learning tools worked as variable $X$ and improving selfregulation and creative thinking skill worked as variable Y. A quasi-experimental research design with a one-shot case study was used as the research method.

Table 1. Calculation results of the eligibility questionnaire score

\begin{tabular}{lllll}
\hline Validator & \multicolumn{2}{l}{ Before Revision } & \multicolumn{2}{l}{ After Revision } \\
\cline { 2 - 5 } & $\begin{array}{l}\text { Media } \\
(\%)\end{array}$ & $\begin{array}{l}\text { Materi } \\
(\%)\end{array}$ & $\begin{array}{l}\text { Media } \\
(\%)\end{array}$ & $\begin{array}{l}\text { Materi } \\
(\%)\end{array}$ \\
\hline Validator 1 & 77.50 & 75 & 83.75 & 90 \\
Validator 2 & 75 & 87.50 & 81 & 95 \\
Mean & 76.25 & 81.25 & 82.38 & 92.50 \\
Total Mean & 78.75 & & 87.44 & \\
\hline
\end{tabular}


Expert and media validation questionnaires, creative thinking skill tests, and self-regulation questionnaires, as well as student response questionnaires were used in this study. The questionnaire is in the form of a Likert model scale, which is an attitude scale. Content and empirical validity tests are used to determine the instrument's validity. Content validity was determined by asking for feedback from two experts on the suitability of the indicators and instrument items developed, while empirical validity was determined by testing the instrument in one of the schools that served as the population but were not included in the research sample (Table 1). According to the N-Gain categorization indicated in table 2 , the increase category can be adjusted.

Table 2. Categorization of N-Gain scores

\begin{tabular}{ll}
\hline Range & Category \\
\hline $0,70-1,00$ & High \\
$0,31-0,69$ & Medium \\
$0-0,30$ & Low \\
\hline
\end{tabular}

(Daryanes \& Fauza, 2020)

The first step in this research is to perform an initial analysis in the form of a needs analysis survey among chemistry teachers at senior high schools in Langsa City utilizing interview questionnaires. The survey data is utilized as a starting point for developing learning tools.

The development of integrated PjBL-STEM elearning tools, as well as expert validation questionnaire instruments and media, creative thinking ability test validation instruments, and student regulatory questionnaire validation instruments, was then completed. Expert content validation data is obtained using the validation instrument. In addition, to acquire empirical validation data, the test instrument for critical thinking skills and self-regulation questionnaires were administered to a population other than the sample.

After the learning tools, test instruments, and questionnaires are valid, then preliminary tests, learning activities, and final tests are carried out on a predetermined sample. The goal is to observe an increase in self-regulation and creative thinking skills. Students' creative thinking skills were analyzed by comparing initial and final test results, while selfregulation data was analyzed by comparing initial and final questionnaire scores.

A response questionnaire was used to get data on the amount of interest in using learning tools. The questionnaire is a closed questionnaire with a list of questions and multiple alternative answers based on a Likert scale.

\section{Result and Discussion}

As shown in table 2, the results of the needs analysis from the interviews were calculated as percentages for each indicator.

Table 3. Percentage of indicators for the needs analysis for the development of chemistry teaching materials

\begin{tabular}{ll}
\hline Indicators & Percentage (\%) \\
\hline $\begin{array}{l}\text { Teacher's perception of teaching } \\
\text { chemistry in the classroom }\end{array}$ & 90 \\
$\begin{array}{l}\text { Teacher's desire to improve the teaching } \\
\text { of chemistry in the classroom }\end{array}$ & 75 \\
$\begin{array}{l}\text { Teacher's desire to increase teaching } \\
\text { potential }\end{array}$ & 80 \\
$\begin{array}{l}\text { Teacher experience in developing } \\
\text { learning tools }\end{array}$ & 70 \\
\hline
\end{tabular}

According to the data in Table 3, teachers' experience in developing learning tools is still insufficient. Indicators of a teacher's desire to improve his teaching, such as the utilization of learning media and the implementation of practicum, likewise reveal a low percentage. Despite the fact that the teacher's perception of teaching in the classroom is generally positive. This is in line with the findings of Sanggara, et al., (2018) study, which found that teachers struggle to provide engaging teaching materials to explain some of the abstract concepts being taught, resulting in poor learning outcomes, particularly in terms of creative thinking skills. Students are not as interested in the process of developing a thought in their minds, which leads to a lack of creative thinking skills (Husein, et al., 2015). As a result, learning tools that can assist teachers in teaching chemistry are required.

The integrated STEM-PjBL e-learning tool is an essential tool for students to improve their higher-order thinking skills. This is in line with the findings of Syukri, et al., (2021) research, which found that developing integrated STEM-PjBL learning tools has a high probability of being used to improve students' science process skills.

Based on the findings of the validation for learning tools, a percentage of $87 \%$ was obtained with valid criteria. Several suggestions for the PjBL-STEM LKPD model were derived from the validation results, as well as suggestions for improving the appearance of the e-learning media used to make it more appealing. The implementation of learning tools (which have been valid) in the sample provides data on creative thinking skills as shown in Figure 1. 


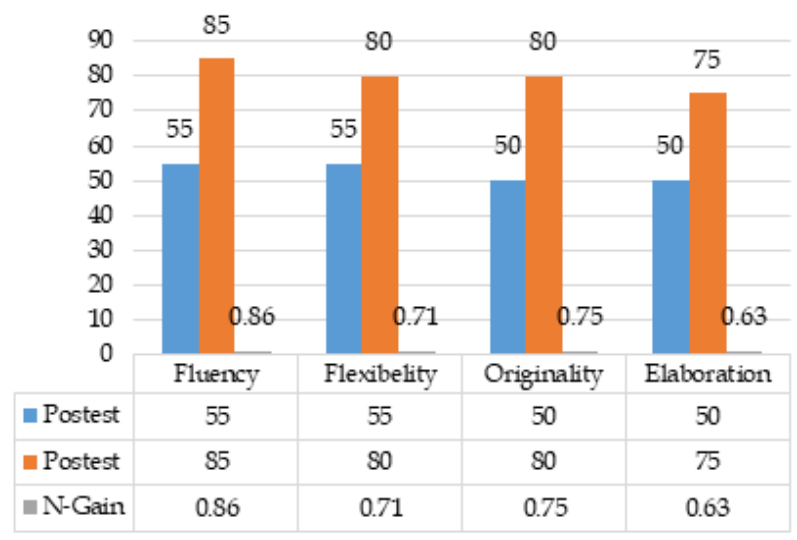

Figure 1. Graphics of the application of PjBL-STEM e-learning tools on creative thinking skills

In each indicator, as shown in Figure 1, the creative thinking skills has improved. The fluency indicator (fluent thinking ability) shows the most improvement, with a score of 0.86 , which falls into the high category. They also improved in the high category for the indicators of flexibility (flexible thinking ability) and originality, with scores of 0.71 and 0.75 , respectively. In terms of the elaboration indicator, the medium category has increased by 0.63 each. The use of learning tools that apply the PjBL-STEM e-learning model produces positive results in terms of improving creative thinking skills. This data is relevant to research Triana, et al., (2020) that shows PjBL-STEM learning improves students' higher-order thinking skills. Furthermore, these findings are consistent with Musa et al., (2012) research, which indicated that the use of integrated $\mathrm{PjBL}$ applications improves 21st-century abilities influenced by application, one of which is the ability to think creatively.

Learning innovations, particularly in PjBL learning and its integration with STEM-based elearning on learning devices, are in line with the characteristics of 21st-century society because learning becomes more engaging, resulting in improved creative thinking skills. According to Rahardjanto et al., (2019) research, PjBL innovations lead to improved learning outcomes in creative thinking skills as well as greater learning motivation. Because it is connected to the internet, this PjBL-STEM e-learning innovation creates a more engaging learning environment. The ability to think creatively will improve as a result of the change to a more pleasant learning environment. This is in line with Triana, et al., (2020) research, which claims that switching to a PjBL-STEM-based learning environment improves students' 4C skills. Furthermore, Astuti et al., (2019) research found that STEM-integrated PjBL improved students' comprehension of ideas and activities in high-category students.

The research data for self-regulation variables are shown in Figure 2.

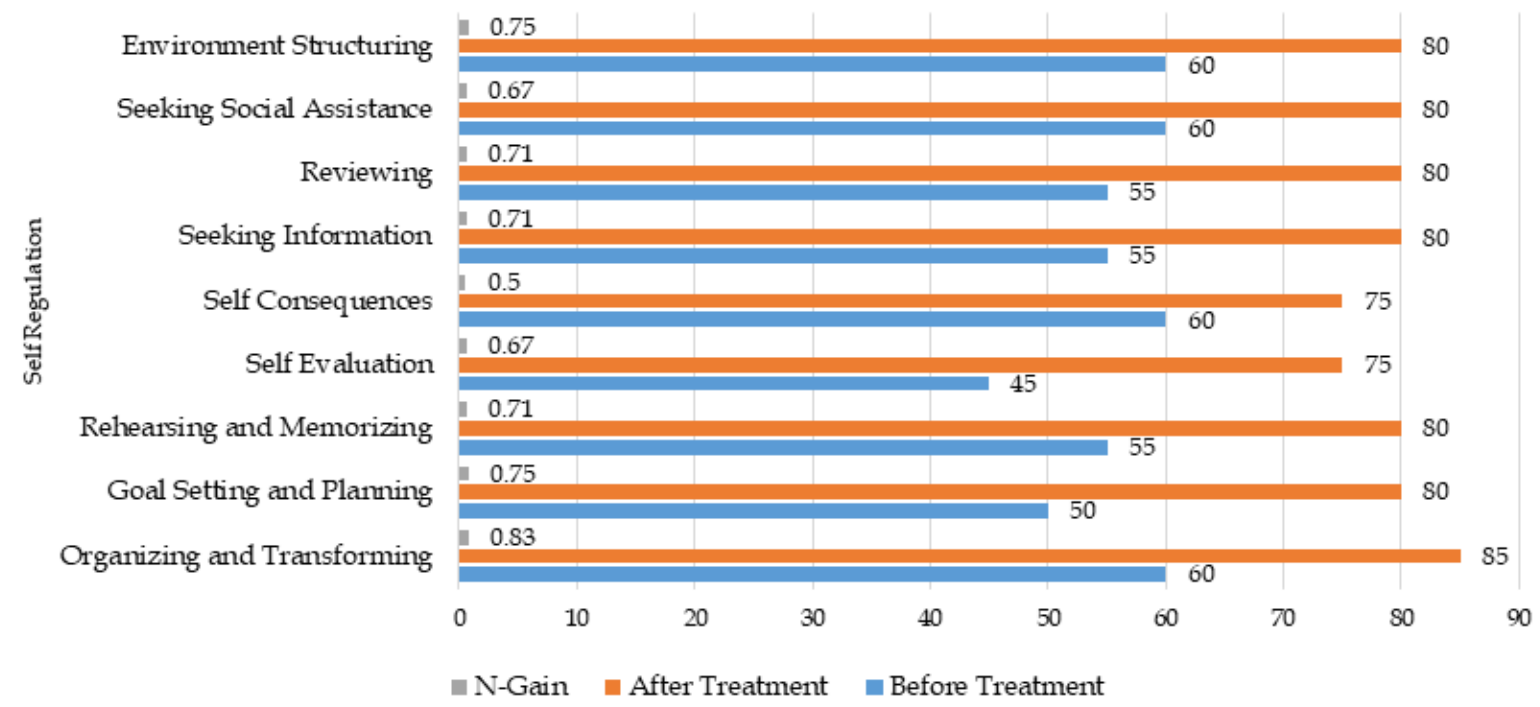

Figure 2. Graph of the application of PjBL-STEM e-learning tools towards self-regulation

Each indicator shows an increase in selfregulation in Figure 2. One indicators, organizing and transforming, saw the greatest increase, with an n-Gain score of 0.83 in the high category. Six of the nine indicators saw a significant increase, while the other three saw a moderate increase. Because students are more engaged in teaching materials that are relevant to their daily needs and in line with growing their creative thinking skills, which in this study used internet-based teaching materials, this high self-regulation rise is 
mainly in organizing and transforming. This is in line with Masse, (2017) findings, which indicate that people actively use media to suit their needs. The use of the internet as a learning medium is one of the efforts to reduce negative internet use so that it can help people develop better self-regulation. This is in line with the findings of Dhahir, (2018) study, which found that the negative impact of the internet can be mitigated by redirecting its use to good activities, resulting in students becoming more responsible individuals. The more self-control you have, the less reliant you are on the internet (Harahap, 2017). The findings of the study in Figure 2 are also consistent with those of Anindyta \& Suwarjo, (2014) study, which found that using PjBL in the classroom improves students' self-regulation and creative thinking skills significantly.

\section{Conclusion}

The development of PjBL-STEM e-learning learning tools resulted in enhanced results in both creative thinking and self-regulation. The average percentage gain in creative thinking skills is 73.66 percent in the high category. The indicator of creative thinking skills receives the highest score on the fluency indicator with a score of 0.86 . The average percentage gain in self-regulation is 79.42 percent in the high category. The self-regulation indicator saw the most improvement in the organizing and transforming indicator with a score of 0.83 . Critical thinking skills can be aligned with self-regulation skills in organizing and transforming so that they complement each other. Based on the findings of the study, it can be stated that developing integrated PjBL-STEM e-learning tools can improve creative thinking skills and self-regulation with high category.

\section{Acknowledgment}

Our gratitude to the Ministry of Education and Culture, Research, and Technology for the financial support of the Research Fund assistance. We would also want to thank the LPPM team of Universitas Samudra for facilitating the research, as well as principals, teachers, and students at State Senior High School in Langsa City, Aceh, who contributed to the implementation of this research.

\section{References}

Anindyta, P., \& Suwarjo, S. (2014). Pengaruh Problem Based Learning Terhadap Keterampilan Berpikir Kritis Dan Regulasi Diri Siswa Kelas V. Jurnal Prima Edukasia, 2(2), 209. https://doi.org/10.21831/jpe.v2i2.2720

Astuti, I. D., Toto, T., \& Yulisma, L. (2019). Model Project Based Learning (PjBL) Terintegrasi STEM Untuk Meningkatkan Penguasaan Konsep dan Aktivitas Belajar Siswa. Quagga: Jurnal Pendidikan Dan Biologi, 11(2), 93. https://doi.org/10.25134/quagga.v11i2.1915

Daryanes, F., \& Fauza, N. (2020). Peningkatan Self Regulation Mahasiswa melalui Strategi Perkuliahan "Students as Researchers" berbasis Online Learning. Bioedusiana: Jurnal Pendidikan Biologi, 5(2), 131-144. https://doi.org/10.37058/bioed.v5i2.2246

Dhahir, D. F. (2018). Pola Asuh Penggunaan Internet di Kalangan Anak-anak Indonesia Internet Parenting upon Indonesian Children. Jurnal Pekommas, 3(2), 169-178. https://jurnal.kominfo.go.id/index.php/pekom mas/article/view/2030206/pdf

Dywan, A. A., \& Airlanda, G. S. (2020). Efektivitas Model Pembelajaran Project Based Learning Berbasis STEM dan Tidak Berbasis STEM terhadap Kemampuan Berpikir Kritis Siswa. Jurnal Basicedu, 4(2), 344-354. https://doi.org/10.31004/basicedu.v4i2.353

Harahap, J. Y. (2017). Hubungan Antara Kontrol Diri Dengan Ketergantungan Internet Di Pustaka Digital Perpustakaan Daerah Medan. Jurnal Edukasi: Jurnal Bimbingan Konseling, 3(2), 131. https://doi.org/10.22373/je.v3i2.3091

Hasanah, Z., Tenri Pada*, A. U., Safrida, S., Artika, W., \& Mudatsir, M. (2021). Implementasi Model Problem Based Learning Dipadu LKPD Berbasis STEM untuk Meningkatkan Keterampilan Berpikir Kritis pada Materi Pencemaran Lingkungan. Jurnal Pendidikan Sains Indonesia, 9(1), 65-75. https://doi.org/10.24815/ipsi.v9i1.18134

Husein, S., Herayanti, L., \& Gunawan, G. (2017). Pengaruh Penggunaan Multimedia Interaktif Terhadap Penguasaan Konsep dan Keterampilan Berpikir Kritis Siswa pada Materi Suhu dan Kalor. Jurnal Pendidikan Fisika dan Teknologi, 1(3), 221-225. http://dx.doi.org/10.29303/jpft.v1i3.262.

Kilınç, A. (2010). Can project-based learning close the gap? Turkish student teachers and proenvironmental behaviours. October, 5(4), 495509.

Masse, M. R. (2017). Internet Dan Penggunaannya (Survei di kalangan masyarakat Kabupaten Takalar Provinsi Sulawesi Selatan). Jurnal Studi Komunikasi Dan Media, 21(1), 13. https://doi.org/10.31445/jskm.2017.210102

Musa, F., Mufti, N., Latiff, R. A., \& Amin, M. M. (2012). 
Project-based Learning (PjBL): Inculcating Soft Skills in 21st Century Workplace. Procedia - Social and Behavioral Sciences, 59(2006), 565-573. https://doi.org/10.1016/j.sbspro.2012.09.315

Nashihuddin, W., \& Aulianto, D. R. (2017). Pengelolaan E-Conference dengan Aplikasi Open Conference System: Upaya Pengembangan Penerbitan Prosiding Online di Indonesia. Khizanah AlHikmah: Jurnal Ilmu Perpustakaan, Informasi, Dan Kearsipan, $5(1)$, $29-49$. https://doi.org/10.24252/kah.v5i1a3

Rachmah, D. N. (2015). Regulasi Diri dalam Belajar pada Mahasiswa yang Memiliki Peran Banyak. Jurnal Psikologi, $42(1), \quad 61$. https://doi.org/10.22146/ipsi.6943

Rahardjanto, A., Husamah, \& Fauzi, A. (2019). HybridPjBL: Learning outcomes, creative thinking skills, and learning motivation of preservice teacher. International Journal of Instruction, 12(2), 179-192. https://doi.org/10.29333/iji.2019.12212a

Sanggara, P. W., Doyan, A., \& Verawati, N. N. S. P. (2018). the Effect of Process Oriented Guided Inquiry Learning Model Based on Virtual Laboraory Toward Problem Solving Abilities of Physics Student. Jurnal Penelitian Pendidikan IPA, 5(1), $1-5$. https://doi.org/10.29303/jppipa.v5i1.154

Sasmita, D., Adlim, M., Gani, A., \& Syukri, M. (2021). Implementation of STEM-based Student Worksheet to Increase Student Entrepreneurial Innovation through the Development of Candied Nutmeg Products. Jurnal Penelitian Pendidikan IPA,

$7(1)$, https://doi.org/10.29303/jppipa.v7i1.551
Syukri, M., Yanti, D. A., Mahzum, E., \& Hamid, A. (2021). Development of a PjBL Model Learning Program Plan based on a STEM Approach to Improve Students' Science Process Skills. Jurnal Penelitian Pendidikan IPA, 7(2), 269. https://doi.org/10.29303/ippipa.v7i2.680

Triana, D., Anggraito, Y. U., \& Ridlo, S. (2020). Effectiveness of Environmental Change Learning Tools Based on STEM-PjBL Towards 4C Skills of Students. Jise, 9(2), 181-187. http://journal.unnes.ac.id/sju/index.php/jise

Umar, M. A. (2016). Penerapan Pendekatan Saintifik dengan Metode Pembelajaran Berbasis Proyek (Project-Based Learning) pada Mata Pelajaran Kimia. Jurnal Entropi, 11(2), 132-138. https://ejournal.stkipbbm.ac.id/index.php/bio/ article/view/194

Utami, I. S., Septiyanto, R. F., Wibowo, F. C., \& Suryana, A. (2017). Pengembangan STEM-A (Science, Technology, Engineering, Mathematic and Animation) Berbasis Kearifan Lokal dalam Pembelajaran Fisika. Jurnal Ilmiah Pendidikan Fisika Al-Biruni, 6(1), 67-73. https://doi.org/10.24042/jpifalbiruni.v6i1.1581

Winaya, I. K. A., Darmawiguna, I. G. M., \& Sindu, I. G. P. (2016). Pengembangan E-Modul Berbasis Project Based Learning Pada Mata Pelajaran Pemrograman Web Kelas X Di Smk Negeri 3 Singaraja. Jurnal Pendidikan Teknologi Dan Kejuruan, 13(2), 198-211. https://doi.org/10.23887/jptk.v13i2.8527 